\title{
NUCLEAR MORPHOLOGY, POLYPLOIDY, AND CHROMATIN ELIMINATION IN TISSUE CULTURE OF ALLIUM FISTULOSUM L.
}

\author{
ANDRZEJ JOACHIMIAK, TOMASZ ILNICKI \\ Department of Plant Cytology and Embryology, Jagiellonian University \\ Grodzka 52, 31-044 Cracow, Poland \\ e-mail: a.joachimiak@iphils.uj.edu.pl
}

(Recived: March 4, 2002. Accepted: December 4, 2002)

\begin{abstract}
The morphology of cell nuclei in callus obtained from root-tip meristems of Allium fistulosum L. (Monocotyledoneae, Alliaceae) was analysed. The most interesting phenomena observed in long-term callus culture were the different mechanisms of cell polyploidization, enlargement of telomeric segments of heterochromatin, and extensive chromatin elimination, associated with instability of nuclei size and DNA content.

Protruding heterochromatin „spikes” were observed on the surface of some di- and polyploid nuclei. The presence of these spikes was connected with the formation of small heterochromatic micronuclei frequently found in the cytoplasm. It is suggested that these micronuclei are produced by direct elimination of heterochromatin from the interphase nuclei.

Polyploid cells accumulated with each successive cell collection. The ploidy level attained by highly polyploid cells was $15 \mathrm{C}-220 \mathrm{C}$. The shape of the nuclei and heterochromatin distribution suggest that polyploid nuclei in $A$. fistulosum tissue culture are produced by endoreduplication and by restitution cycles.
\end{abstract}

KEY WORDS: Allium, tissue culture, heterochromatin, elimination, telomere, polyploidization, micronuclei.

\section{INTRODUCTION}

Genetic alterations in calli can be examined in many ways. Changes in chromosome number and nuclear DNA amount are analysed more often than abnormalities in the structure of chromosomes and interphase nuclei. Cytophotometry, densitometry and chromosome counting have generally revealed increased production of polyploid and aneuploid cells in cultured plant tissues. In some long-cultured calli almost all of the diploid cells are eliminated and replaced by polyploid cells (Bayliss 1980; Golczyk 1994). It has been suggested, however, that in some plant cultures opposite mechanisms operate, which decrease chromosome number and cell ploidy level (Nuti Ronchi 1991; Madej and Kuta 2001). Chromosome and DNA stability during in vitro culture is rather exceptionally observed, mainly in some nonpolysomatic plants, but even in such plants the chromosomal stability is not permanent. For example, in callus of monosomatic plant, Crepis capillaris the chromosomal stability is limited to about one year of culture and then polyploid cells appear successively (Maluszynska 1997).

Here we report observations of nuclear morphology in tissue culture of Allium fistulosum, with special reference to heterochromatin amounts and distributions. In long-term callus culture of this species a tendency to cell polyploidization and chromatin elimination was observed. Micronuclei were detected in the cytoplasm of many di- and polyploid cells and many nuclei exhibited peripheral structures (Joachimiak et al. 1993) similar to the spikes found in Dendrobium and Scilla (Nagl 1983; Deumling and Clermont 1989).

\section{MATERIAL AND METHODS}

Seeds of Allium fistulosum cv. 'Motokura' were provided by Dr. Akio Kojima (Tohoku University, Japan).

Callus obtained from root tips of germinating seedlings served as the material for study. The methods of callus induction and culture were the same as described previously (Joachimiak et al. 1993, 1995). For cytogenetic analysis the samples were collected and fixed in acetic alcohol (1:3) every four months. Pieces of callus were rinsed and squashes or spreads were made.

The relative amounts of nuclear DNA (in arbitrary units) were estimated densitometrically. Preparations were Feulgen-stained with pararosaniline (Sigma) according to the procedure described by Bennett et al. (1998). Standards for 
2C and 4C levels were obtained from telophases and prophases from meristem root tips of A. fistulosum $\mathrm{cv}$. 'Motokura'. The morphology of nuclei and chromosomes and the heterochromatin and DNA amounts were analysed with the Lucia G system (Laboratory Imaging Ltd.). Microscopic images were transferred to the system via a videocamera. In each of six collections about 3000 cells were screened to establish the heterochromatin distribution and frequency of micronuclei, and at least 1000 nuclei were analysed densitometrically.

\section{Cytological methods}

The material was rinsed a few times in distilled water, hydrolyzed in $1 \mathrm{~N} \mathrm{HCl}$ at $60^{\circ} \mathrm{C}$ for $11 \mathrm{~min}$, and stained in pararosaniline according to the Feulgen method (FM). For C-banding (CB), pieces of callus were rinsed several times in distilled water and squashes or spreads were made. Cell squashes obtained by the dry-ice method or slides with cell spreads (Geber and Schweizer, 1988) were kept in the open air to dry for 1-7 days and stained by the method described by Schwarzacher et al. (1980). The preparations were made permanent and are kept in the Department of Plant Cytology and Embryology, Jagiellonian University, Cracow.

Fluorescent staining was done using a $0.5 \%$ aequeous solution of Acridine Orange (AO) or buffered $(\mathrm{pH} 7) 33258$ Hoechst $(\mathrm{H})$ solution $(0.2 \mathrm{mg} / \mathrm{ml})$ diluted from an aequeous stock solution. Stained preparations were rinsed in tap water $(\mathrm{AO})$ or neutral phosphate buffer $(\mathrm{H})$, dried in the open air and sealed in $5 \mathrm{mM}$ phosphate buffer $\left(\mathrm{Na}_{2} \mathrm{HPO}_{4}+\right.$ $\mathrm{NaH}_{2} \mathrm{PO}_{4}$ ) with $1 \mathrm{mM}$ EDTA, $\mathrm{pH} 7$.

\section{RESULTS}

All 16 chromosomes of A. fistulosum have solid C-positive blocks at the telomeres (Fig. 1a). In the majority of Cbanded nuclei there were 16-20 large heterochromatic segments, corresponding in size to the large blocks in the chromosomes (Fig. 1b). However, the number 32 of telomeric heterochromatin blocks in the diploid chromosome complement was about twice the average number of large blocks in the nuclei. The reduction of the number of telomeric segments may indicate telomere fusion during inter- phase, conditioned by the similar molecular structure of repetitive telomeric sequences or the spatial ordering of chromosomes during interphase (Fussell 1984; Noguchi and Fukui 1995). Such telomeric fusions have been observed in cell nuclei of A. cepa (Fussell 1975, 1977; Barnes et al. 1985; Joachimiak 1987).

In the initial Allium fistulosum cultures, all the cell nuclei were similar in shape and size to the nuclei of the meristem. Their average surface area was about $100 \mu^{2}$, with a minimum size of $61 \mathrm{~mm}^{2}$ (telophase nuclei) and a maximum size of $224 \mu^{2}$ (early prophase nuclei). The observed metaphases at this stage all had a diploid $(2 \mathrm{n}=16)$ chromosome number. In the second collection the average size of nuclei slightly decreased $\left(88 \mu \mathrm{m}^{2}\right)$, probably as a result of chromatin elimination from diploid nuclei. Indeed, about $1.5 \%$ of the cells possessed 1-2 very small micronuclei at this stage, and a small number of cells had larger micronuclei resulting from rarely observed mitotic elimination of intact chromosomes (Figs 2, 3). Additionally a tendency to cell polyploidization was evidenced, and a few metaphases with the tetraploid number of chromosomes were observed. Some late-prophase nuclei reached over $1000 \mu^{2}$, which suggests that they represented higher ploidy levels. More large polyploid cells were observed at each successive collection. After two years of culture, cells with giant nuclei were observed in the callus (Fig. 4). The DNA levels (determined densitometrically) attained by these large cells were 15C-220C (Fig. 13). Some polyploid nuclei were irregular in shape, indicative of mitotic disturbances (Fig. 5). High-polyploid cells were not dispersed randomly among di- and tetraploid cells, but accumulated in clearly visible clusters (Fig. 5). Sporadically, some high-polyploid cells may have entered and perhaps even completed mitosis, as is suggested by the high-polyploid prophases and metaphases observed in the analysed material (Fig. 6).

The frequency of cells with micronuclei in further collections slowly increased and reached about 4\%. In the majority of these cells, 1-2 micronuclei were observed, but in some polyploid cells the number of micronuclei was higher - up to 14. Differences in the sizes of micronuclei within one cell were also seen.

In respect to heterochromatin distribution, two types of highly polyploid nuclei occurred in C-banded material. In a

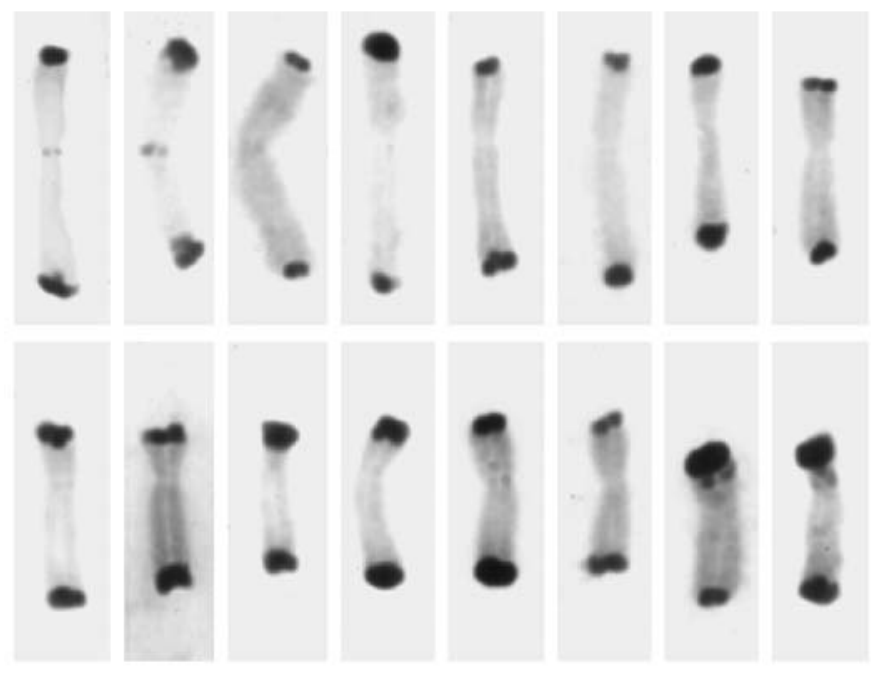

b

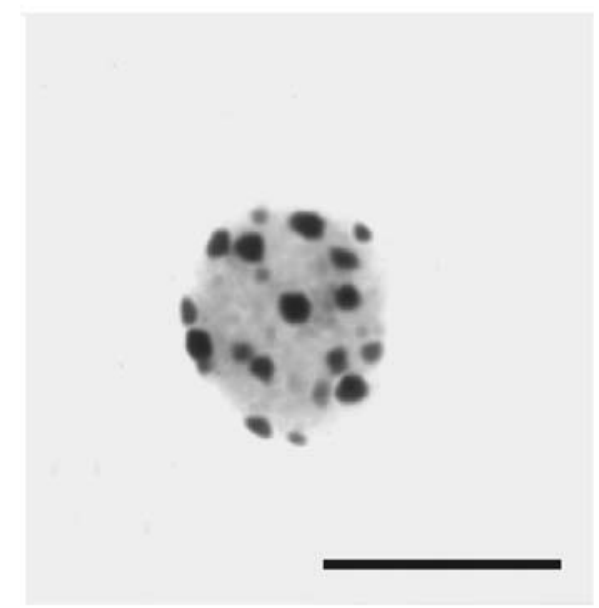

Fig. 1. C-banding in root-tips of Allium fistulosum; a - diploid chromosome complement, $\mathrm{b}-$ diploid nucleus. Bar $=10 \mu \mathrm{m}$. 

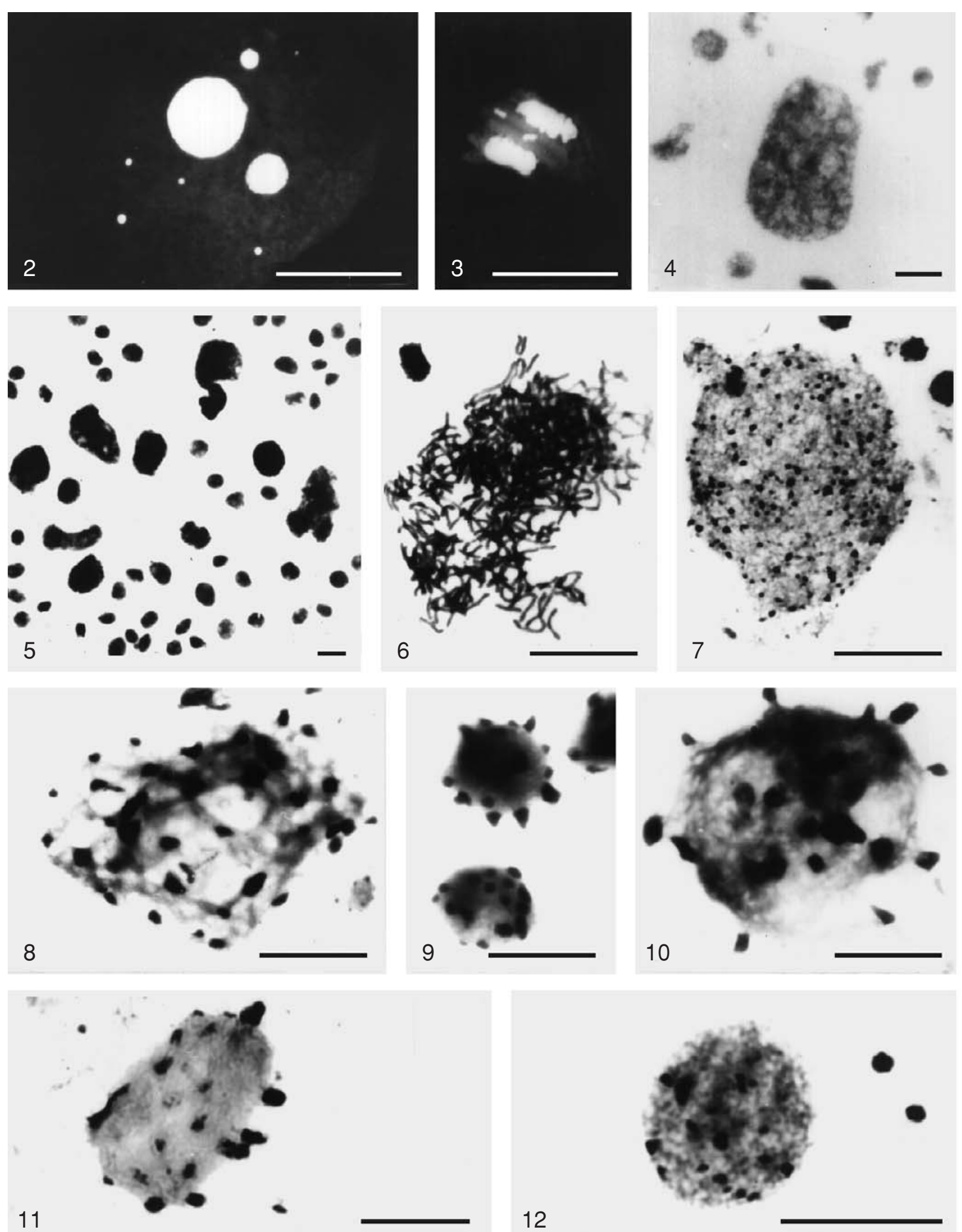

Figs 2-12. Allium fistulosum tissue culture, Fig. 2. Cell with micronuclei (H), Fig. 3. Chromosome elimination at anaphase (AO), Fig. 4. High-polyploid (32C) nucleus (FM), Fig. 5. Cluster of cells with polyploid nuclei (FM), Fig. 6. High-polyploid metaphase plate (FM), Figs 7, 8. Polyploid nuclei with different numbers and sizes of heterochromatic segments (CB), Figs 9-11. Nuclei with heterochromatic spikes (CB), Fig. 12. Heterochromatic micronuclei (CB). Bar $=20 \mu \mathrm{m}$. 
the first type (Fig. 7) many (up to 500) relatively small heterochromatin segments were scored, similar in size to the telomeric bands of chromosomes and nuclei in the initial exhibited a limited number of larger heterochromatin segments after C-banding. In the majority of cases the number of these segments (i.e., the number of telomeric segments in diploid nuclei) was 16-32. The distributions of heterochromatin suggest that the two types of polyploid nuclei observed in the callus are of different origin. The nuclei with a large number of small heterochromatin segments probably are produced by restitution, and the nuclei of the second type by endopolyploidization.

The most interesting phenomenon in the analysed material was the occurrence of clearly visible heterochromatin spikes on the surface of some diploid and polyploid nuclei of many cells after these spikes disappeared. These micronuclei were often heterochromatic (Fig. 12) and probably were produced by elimination of heterochromatic spikes

In mitotic chromosomes the heterochromatic termini were not substantially shortened. Almost all altered and unaltered chromosomes in the calli showed typical heterochromatin blocks at the telomeres (Joachimiak et al. 1995). Thus, the cell collection. The second type of polyploid nuclei (Fig. 8) (Figs 9-11). Small micronuclei appeared in the cytoplasm from the nuclei.

elimination of heterochromatin from nuclei seems not to be correlated with a corresponding quantitative elimination of telomeric heterochromatin from chromosomes.

\section{DISCUSSION}

During in vitro culture, plant tissues undergo distinct structural and functional changes. Some observed genetic alterations probably have an adaptative value for cells and tissues exposed to experimental conditions. However, the function of particular agents in the induction of these alterations in calli is not well recognized. In long-term in vitro culture only particular cell lines well adapted to the experimental conditions are selected and are capable of effective reproduction. Such lines display more vitality and proliferative efficiency than many others occurring in the original explant or produced by various mutations.

After two years of culture the callus remains in a nonstabilized state, and is composed of cells with different levels of ploidy, but diploid and tetraploid cells are still represented in relatively high numbers. Some high-polyploid cells may also reenter proliferation; thus, polyploid prophases and metaphases were observed. As Nuti Ronchi (1991) suggested, the reentry of the proliferating pool by high-po-

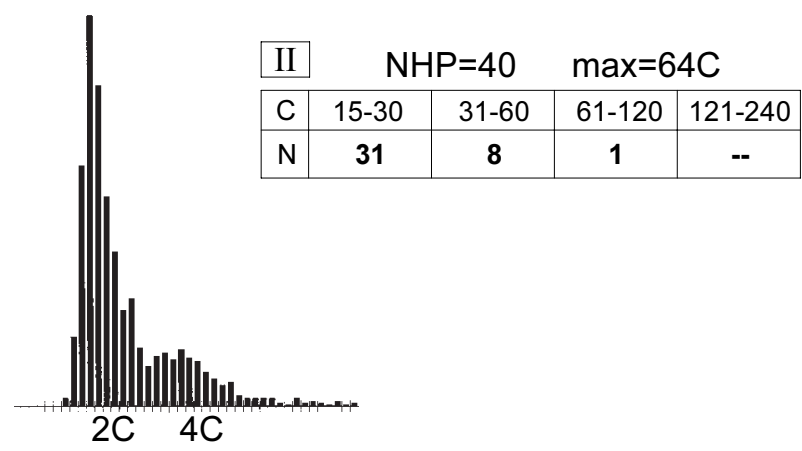

\begin{tabular}{|c|c|c|c|c|}
\hline III & \multicolumn{2}{c}{ NHP=34 } & \multicolumn{2}{c|}{$\max =50 \mathrm{C}$} \\
\hline C & $15-30$ & $31-60$ & $61-120$ & $121-240$ \\
\hline N & $\mathbf{3 2}$ & $\mathbf{2}$ & -- & -- \\
\hline
\end{tabular}

2C $\quad 4 \mathrm{C}$

\begin{tabular}{|c|c|c|c|c|}
\hline \multicolumn{1}{|c|}{ I } & \multicolumn{2}{c}{ NHP=0 } & \multicolumn{2}{c}{$\max =8 \mathrm{C}$} \\
\hline $\mathrm{C}$ & $15-30$ & $31-60$ & $61-120$ & $121-240$ \\
\hline N & -- & -- & -- & -- \\
\hline
\end{tabular}

$2 \mathrm{C} \quad 4 \mathrm{C}$
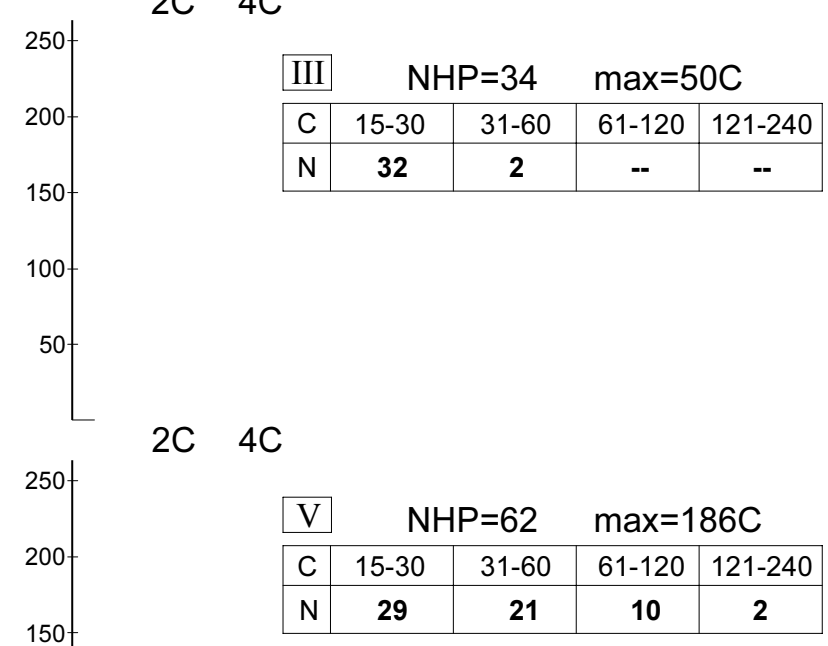

$2 C \quad 4 C \quad 6 C \quad 8 C \quad 10 C \quad 12 C$
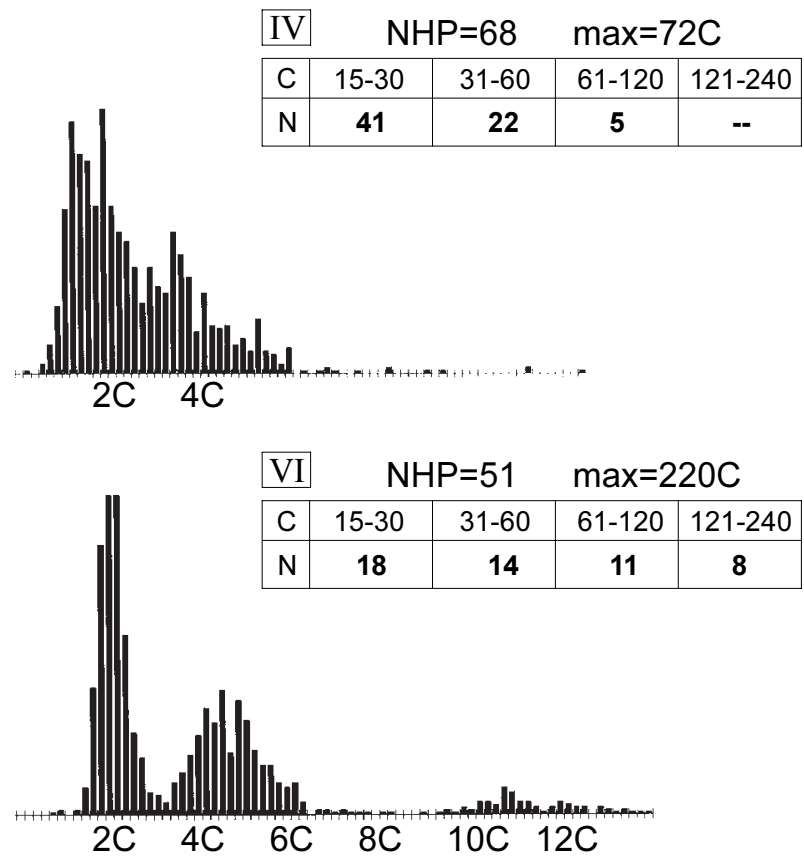

Fig. 13. Allium fistulosum tissue culture - distribution of nuclear DNA content in 6 cell collections. Frequency of high-polyploid (more than 15C) nuclei in each collection is presented in Tables I-VI (C - C-values, $\mathrm{N}$ - number of nuclei); NHP - number of detected high- polyploid nuclei, max - maximum nuclear DNA content. 
lyploid cells may reduce ploidy levels and produce highly heterogenous cell populations in cultures. Indeed, A. fistulosum cultures consist of cells with different DNA content (Fig. 13), and nuclei sizes. The alterations in nuclear morphology described here were accompanied by numerous types of chromosome aberrations, among which the megachromosomes were especially interesting (Joachimiak et al. 1993). The essential role of telomeric heterochromatin in chromosome rearrangements and the mechanisms giving rise to aberrant chromosome types in A. fistulosum were described previously (Joachimiak et al. 1995).

Cell polyploidization in plant tissue culture has been described in many experimental systems, but in the majority of cases the observed ploidy levels are not very high (Bayliss 1980). The maximum nuclear DNA levels detected in another Allium tissue culture were 16C-64C, but the frequency of these high-polyploid nuclei was rather low (Allium sativum - Dolezel and Novak 1985). Similar to the high ploidy levels observed here were those reported by Nagl (1993) for cultured cells of Phaseolus coccineus treated with K-252a, an inhibitor of protein kinase activity. The treatment resulted in continuous reduplication cycles, and some cell nuclei reached extremely high ploidy levels, up to 2048C. As has been observed in Allium fistulosum, even within one callus two different ways may be responsible for cell polyploidization. Some cell nuclei undergo endoreduplication; others reach polyploidy by restitution cycles. The apparent lack of nuclei with a great number of enlarged heterochromatin segments suggests that endoreduplication is possible in tissue culture of A. fistulosum only in cells that did not undergo inhibited divisions previously.

Heterochromatin elimination or accumulation are other phenomena related to the nuclear changes observed in calli. Heterochromatin elimination in Allium fistulosum was probably connected with the formation of heterochromatic spikes on the surface of the nuclei, as in Dendrobium (Nagl 1983) and Scilla (Deumling and Clermont 1989). Such direct heterochromatin elimination from cell nuclei, although extremely rare in plants, is more frequently observed during ontogenesis of some animals (,chromatin diminution") (Tobler et al. 1972; Beermann 1977; Goday and Pimpinelli 1986; Esteban et al. 1995; Kubota et al. 1997; Goto et al. 1998). In this type of elimination, the relative heterochromatin amount decreases in the karyotype of some somatic cell lines (or in the vegetative macronucleus of ciliates: Smothers et al. 1997). Preferential elimination of chromatin into micronuclei was also observed in some experiments with human cells, treated by chemicals inducing undercondensation of heterochromatin (Tommerup 1984, Guttenbach and Schmid 1994).

The formed micronuclei must have been eliminated, as their gradual accumulation during culture was not evidenced. Since the elimination of heterochromatin was continuously observed during culture, reduction of the heterochromatin amount in chromosomes and nuclei was expected. The relatively low frequency of nuclei and chromosomes with reduced amounts of heterochromatin (Joachimiak et al. 1995) suggests at least two possibilities: (1) cells with reduced amounts of heterochromatin are not efficient growers and cannot continously proliferate in culture, or (2) heterochromatin elimination is balanced by heterochromatin amplification. Observations of nuclei with extended C- positive segments (Fig. 11) probably composed of telomeric heterochromatin support the second possibility.

If the telomeric heterochromatin segments observed in Allium fistulosum occupy the chromosome termini (in $\mathrm{Al}$ lium sect. Cepa characteristic telomeric plant repeats TTTAGGG are absent and are replaced by highly repetitive heterochromatic sequences: Fuchs et al. 1995; Pich et al. 1996a, b; Pich and Schubert 1998; Stevenson et al. 1999), the observed alterations in telomeric heterochromatin may be the result of damage to the mechanisms responsible for limiting the growth of these sequences. The mechanism of telomere elongation in A. fistulosum is not recognized, but it has been suggested (Pich and Schubert 1998) that the replication-mediated shortening of chromosome ends in this species could be compensated by recombination or conversion, as in dipteran insects (Biessmann and Mason 1997; Mikhailovsky et al. 1999, for review).

The activation of the mechanism of heterochromatic termini elongation in Allium tissue culture is probably responsible for „,chromosome healing” (addition of new telomeric heterochromatin to broken chromosome arms). In successive cell collections from the long-cultured A. fistulosum calli the frequency of unusually short „minichromosomes” increased (Joachimiak et al. 1995). The minichromosomes are equipped with telomeric heterochromatin at the ends of both arms; most probably these heterochromatic termini were produced de novo by adding heterochromatin to the short centric fragments produced frequently in culture by chromosome breakage. Tsujimoto et al. $(1997,1999)$ found similar healing of broken chromosome ends in vivo in wheat.

The somaclonal variation arising from explants cultured in vitro has found applications in plant breeding, and it is suggested that under these conditions variant regenerated plants occur at frequencies much higher than those obtained under more common mutagenic treatments (Karp 1991). From this point of view the mechanisms responsible for heterochromatin variability in calli are of special interest, because of the role of this chromosome fraction in inducing chromosome alterations (Joachimiak et al., 1995; Fluminhan et al. 1996, for review), in its influence on the embryogenic response (Fluminhan and Aguiar-Perecin 1998), and in affecting variation and agronomic traits in regenerated plants (Kaltsikes and Bebeli 1992; Bebeli and Kaltsikes 1994; Bebeli et al. 1993).

\section{ACKNOWLEDGEMENTS}

This research was supported by The State Committee For Scientific Research (KBN) grant no. 6 P204 06606.

\section{LITERATURE CITED}

BARNES S.R., JAMES A.M., JAMIESON G. 1985. The organisation, nucleotide sequence, and chromosomal distribution of a satellite DNA from Allium cepa. Chromosoma 92: 185-192.

BAYLISS M.W. 1980. Chromosomal variation in plant tissues culture. Int. Rev. Cytol. Suppl. 11a: 113-144.

BEBELI P.J., KALTSIKES P.J. 1994. Superior R3 families in rye through tissue culture. J. Genet. \& Breed. 48: 371-376.

BEBELI P.J., KALTSIKES P.J., KARP A. 1993. Field evaluation of somaclonal variation in rye lines differing in telomeric heterochromatin. J. Genet. \& Breed. 47: 15-22. 
BEERMANN S. 1977. The diminution of heterochromatic chromosomal segments in Cyclops (Crustacea, Copepoda). Chromosoma 60: 297-344.

BENNETT M.D., LEITCH I.J., HANSON L. 1998. DNA amounts in two samples of angiosperm weeds. Ann. Bot. 82 (Suppl. A): 121-134.

BIESSMANN H., MASON J.M. 1997. Telomere maintenance without telomerase. Chromosoma 106: 63-69.

DEUMLING B., CLERMONT L. 1989. Changes in DNA content and chromosomal size during cell culture and plant regeneration of Scilla siberica; selective chromatin diminution in response to environmental conditions. Chromosoma 97: 439-448.

DOLEZEL J., NOVAK F. 1985. Karyological and cytophotometric study of callus induction in Allium sativum L. J. Plant Physiol. 118: 421-429.

ESTEBAN M.R., GIOVINAZZO G., GODAY C. 1995. Chromatin diminution is strictly correlated to somatic cell behavior in early development of the nematode Parascaris univalens. J. Cell Sci. 108: 2393-2404.

FLUMINHAN A., AGUIAR-PERECIN M.L.R., SANTOS J.A. 1996. Evidence for heterochromatin involvement in chromosome breakage in maize callus culture. Ann. Bot. 78: 73-81.

FLUMINHAN A., AGUIAR-PERECIN M.L.R. 1998. Embryogenic response and mitotic instability in callus cultures derived from maize inbred lines differing in heterochromatic knob content of chromosomes. Ann. Bot. 82: 569-576.

FUCHS J., BRANDES A., SCHUBERT I. 1995. Telomere sequence localization and karyotype evolution in higher plants. Pl. Syst. Evol. 196: 227-241.

FUSSELL C.P. 1975. The position of interphase chromosomes and late replicating DNA in centromere and telomere regions of Allium cepa L. Chromosoma 50: 201-210.

FUSSELL C.P. 1977. Telomere associations in interphase nuclei of Allium cepa demonstrated by C-banding. Exp. Cell Res. 110: 111.

FUSSELL C.P. 1984. Interphase chromosome order: A proposal. Genetica 62: 193-201.

GEBER G., SCHWEIZER D. 1988. Cytochemical heterochromatin differentiation in Sinapsis alba (Cruciferae) using a simple air-drying technique for producing chromosome spreads. Pl. Syst. Evol. 158: 97-106.

GODAY C., PIMPINELLI S. 1986. Cytological analysis of chromosomes in the two species Parascaris univalens and $P$. equorum. Chromosoma 94: 1-10.

GOLCZYK H. 1994. Cytological changes in tissue culture of $A l$ lium sibiricum L. Acta Biol. Cracov. Ser. Bot. 36: 31-36.

GOTO Y., KUBOTA S., KOHNO S. 1998. Highly repetitive sequences that are restricted to the germ line in the hagfish Eptatretus cirrhatus: a mosaic of eliminated elements. Chromosoma 107: 17-32.

GUTTENBACH M., SCHMID M. 1994. Exclusion of specific human chromosomes into micronuclei by 5 -azacytidine treatment of lymphocyte cultures. Exp. Cell Res. 211: 127-132.

JOACHIMIAK A. 1987. Telomere arrangement in interphase nuclei of Allium cepa L. Acta Biol. Cracov. Ser. Bot. 29: 64-70.

JOACHIMIAK A., PRZYWARA L., ILNICKI T., KOWALSKA A. 1993. Megachromosomes in tissue culture of Allium. Genetica 90: 35-40.

JOACHIMIAK A., ILNICKI T., KOWALSKA A., PRZYWARA L. 1995. Chromosome alterations in tissue culture cells of $\mathrm{Al}$ lium fistulosum. Genetica 96: 191-198.

KALTSIKES P.J., BEBELI P.J. 1992. The effect of rye telomeric heterochromatin on the nature and size of variance in regenerated families of hexaploid triticale. J. Genet. \& Breed. 46: 359-362.
KARP A. 1991. On the current understanding of somaclonal variation. In: Mifflin B.J. (ed) Oxford Surveys of Plant Molecular and Cell Biology. Oxford University Press, Oxford. pp 1-58.

KUBOTA S., ISHIBASHI T., KOHNO S. 1997. A germline restricted, highly repetitive DNA sequence in Paramyxine atami: an interspecifically conserved, but somatically eliminated element. Mol. Gen. Genet. 256: 252-256.

MADEJ A., KUTA E. 2001. Holokinetic chromosomes of Luzula luzuloides (Juncaceae) in callus culture. Acta Biol. Cracov. Ser. Bot. 43: 33-43.

MALUSZYNSKA J. 1997. The effect of B chromosomes and TDNA on chromosomal variation in callus cells and regenerated roots of Crepis capillaris. Pl. Cell. Tiss. Org. Cult. 50: 113-118 .

MIKHAILOVSKY S., BELENKAYA T., GEORGIEV P. 1999. Broken chromosome ends can be elongated by conversion in Drosophila melanogaster. Chromosoma 108: 114-120.

NAGL W. 1983. Heterochromatin elimination in the orchid Dendrobium. Protoplasma 118: 234-237.

NAGL W. 1993. Induction of high polyploidy in Phaseolus cell cultures by the protein kinase inhibitor, K-252a. Plant Cell Rep. 12: 170-174.

NOGUCHI J., FUKUI K. 1995. Chromatin arrangements in intact interphase nuclei examined by laser confocal microscopy. J. Plant Res. 108: 209-216.

NUTI RONCHI V. 1991. Biological and genetic features of cell cultures in relation to plant morphogenesis. Newsletter IAPTC 65: 2-12.

PICH U., FRITSCH R., SCHUBERT I. 1996a. Closely related Allium species (Alliaceae) share a very similar satellite sequence. Pl. Syst. Evol. 202: 255-264.

PICH U., FUCHS J., SCHUBERT I. 1996b. How do Alliaceae stabilize their chromosome ends in the absence of TTTAGGG sequences? Chromosome Res. 4: 207-213.

PICH U., SCHUBERT I. 1998. Terminal heterochromatin and alternative telomeric sequences in Allium cepa. Chromosome Res. 6: 315-321

SCHWARZACHER T., AMBROS P., SCHWEIZER D. 1980. Application of Giemsa banding to orchid karyotype analysis. Pl. Syst. Evol. 134: 293-297.

SMOTHERS J.F., MIZZEN C.A., TUBBERT M.M., COOK R.G., ALLIS C.D. 1997. Pdd1p associates with germline-restricted chromatin and a second novel anlagen-enriched protein in developmentally programmed DNA elimination structures. Development 124: 4537-4545.

STEVENSON M., ARMSTRONG S.J., JONES G.H., FORDLLOYD B.V. 1999. Distribution of a 375 bp repeat sequence in Allium (Alliaceae) as revealed by FISH. Pl. Syst. Evol. 217: 31-42.

TOBLER H., SMITH K.P., URSPRUNG H. 1972. Molecular aspect of chromatin elimination in Ascaris lumbricoides. Dev. Biol. 27: 190-203.

TOMMERUP N. 1984. Idoxuridine induction of micronuclei containing the long or short arms of human chromosome 9. Cell Genet. 38: 92-98.

TSUJIMOTO H., YAMADA T., SASAKUMA T. 1997. Molecular structure of a wheat chromosome end healed after gametocidal gene-induced breakage. Proc. Natl. Acad. Sci. USA 94: 3140-3144.

TSUJIMOTO H., USAMI N., HASEGAWA K., YAMADA T., NAGAKI K., SASAKUMA T. 1999. De novo synthesis of telomere sequences at the healed breakpoints of wheat deletion chromosomes. Mol. Gen. Genet. 262: 851-856. 


\section{MORFOLOGIA JĄDER, POLIPLOIDALNOŚĆ I ELIMINACJA CHROMATYNY W KULTURACH TKANKOWYCH ALLIUM FISTULOSUM L. \\ STRESZCZENIE}

Analizowano morfologię jąder komórkowych w komórkach kalusa wyprowadzonego z merystemu korzeniowego Allium fistulosum L. Najbardziej interesującymi zjawiskami stwierdzonymi w długoterminowej hodowli tego kalusa były: różne mechanizmy poliploidyzacji komórek, amplifikacja telomerycznej heterochromatyny, eliminacja chromatyny bezpośrednio z jąder komórkowych i wysoka niestabilność jąder komórkowych, zarówno pod względem względnej zawartości DNA jak i kształtu.

W obrębie niektórych jąder obserwowano wystające heterochromatynowe „wyrostki”. Obecność tych struktur miała związek z eliminacją heterochromatyny i formowaniem mikrojąder obserwowanych często w cytoplazmie komórek kalusa.

Liczba poliploidalnych komórek wzrastała z wiekiem hodowli. Niektóre z nich zawierały jądra o wyjątkowo wysokim stopniu ploidalności (15-220 n). Kształt poliploidalnych jąder oraz liczba i dystrybucja segmentów heterochromatynowych w ich obrębie sugerują, że powstały one albo na drodze reduplikacji, albo restytucji.

SŁOWA KLUCZOWE: Allium, kultura tkankowa, heterochromatyna, eliminacja, telomer, poliploidyzacja, mikrojądra. 